\title{
SOCIAL SCIENTIST ON BOARD IN LONG-TERM MANAGEMENT OF HIGH LEVEL AND/OR LONG-LIVED RADIOACTIVE WASTE IN BELGIUM
}

\author{
C. Parotte \\ Spiral Research Center \\ Department of Political Sciences \\ Faculty of Law \\ University of Liège \\ Belgium
}

\begin{abstract}
In Belgium, the long-term management of radioactive waste is under the exclusive competence of the Belgian Agency for Radioactive Waste and Enriched Fissile Materials (knew as ONDRAF/NIRAS). Unlike low-level waste, no institutional policy has yet been formally approved for the long-term management of high level and/or long-lived radioactive waste (knew as B\&C waste). In this context, ONDRAF/NIRAS considers the public and stakeholders' participation as an essential factor in the formulation of an effective and legitimate policy. This is why it has decided to integrate them in different ways during the elaboration of the Waste Plan (ONDRAF/NIRAS-document containing guidelines to make a principled policy decision about nuclear waste management). To do so, social scientists have been regularly mobilized either as external evaluators, follow-up committee members, or participatory observants. Hence, the Waste Plan is only the first step in a long decision-making process.

For a PhD student under contract with ONDRAF/NIRAS, this mandate consists of thinking out a way to construct an inter-organizational innovative communication system that would be participative, transparent and embedded in a longterm perspective, thus integrating all the further legal steps to take throughout the decision-making process. In this regard, two paradoxical constraints must be taken into account: on the one hand, my own influence on the legal decision-making process should remain limited, because of a series of constraints, lock-ins and previous decisions which have to be
\end{abstract}

respected; on the other hand, ONDRAF/NIRAS expects the research conclusions to be policy relevant and useful.

In this paper, the purpose is twofold. Firstly, the issues raised by this policy mandate is an opportunity to question the performative dimensions of the social scientist in the decisionmaking process and, more specifically, to have a reflexive view on our position as PhD Student. Secondly, assuming the role of "embarked" social scientist, numerous of answers will discuss to face the different dilemmas of the researcher "in action". Those reflections follow on, among others, those from previous papers discussed in Quimper in April 2013 [1] and in Leuven in June 2013 [2].

\section{INTRODUCTION}

Nowadays, the integration of a participatory approach in the process of radioactive waste management goes unquestioned. Indeed, in Belgium, this dimension indeed appears crucial given the international and European consensus on the subject [3-4] as well as the stumbling blocks already met in the country with the management of low-level radioactive waste [5]. This state of a mandatory integration of the societal dimension in the problem of radioactive waste management requires the mobilization of a new area of expertise: the social sciences.

This paper aims to be a practice of (self)reflexivity toward a researcher's own position; How have social scientists been mobilized in long-term management of high level and/or longlived radioactive waste? More broadly, how should the social scientist engage with the actors he studies and under which 
conditions does he study them? Following the statements of Skolits and al. [6], an inductive and a pragmatic approach based was adopted on his empirical experiences with the ONDRAF/NIRAS. The social scientific activity is analyzed in regard of three dimensions developed by Laurent and Van Oudheusden [7]: the relationship of the social scientist with the actors he studies, the policy relevance of his/her work and the problems the social scientist has to deal with.

This paper is divided in three sections. The first chapter will specify our methodological approach, the relevant factors of the context as well as the main actors we engage with. The second chapter traces the evolution of the commitment of the social scientist, from the first participatory activities associated with the Waste Plan until now, i.e. from 2009 until 2013. Hence, the analysis doesn't cover the whole history of societal aspects integration in the nuclear field but is restricted to a timeframe whereas the engagement of social scientists is taken-for-granted [8]. In the second section, we will distinguish between two different periods; the issues of the PhD Research and the others participatory activities. Finally, the third section will discuss a couple of solutions, in a foresight perspective, to cope with the different dilemmas faced by the social scientist "in action".

\section{MULTIPLES ROLES FOR THE SOCIAL SCIENTIST}

\section{Many roles, many categories}

According to many authors $[9,10,11,12]$, the role of the social scientist is usually unclear especially since he must endorse various research goals at the same time. The different categories proposed in the literature to classify those various roles vary a great deal. For instance, Jones and Irwin [13] divide social scientist's role in two main categories: the experts representatives of the public (able to be witnesses and at the same time, communicators, capable of carrying out a technical problem in its social context) and the experts who complement the technical experts ("challengers" capable of helping the technical experts to recognize the technical limits of their work). Lits $[14,15]$ classifies the roles identified by Jones and Irwin in the category of "informant/legitimizing researcher". He adds two others one: on the one hand, the "engineer/mediator sociologist" (his role is to build participatory instruments adapted to the context) and on the other hand, the critical sociologist (close to the role of the "challenger"). Wendling [16] argues that most researchers in social sciences ideally wish to take place in this last category of the critical sociologist. But contrary to Lits, she considers that the evaluation of the social scientist has to intervene after the process, rather than before or during this process. However, they both use the same definition to describe the critical sociologist. He provides "wisdom sitting above the fray', metaanalyzes of how risks are dealt with (while analysing frame of reference and the risk assessment process or monitoring effects ex post) [17]." At least, Skolits et al. [18] identify four main categories in their current evaluation literature review: The roles driven by the evaluation methods, the roles defined by evaluation models [19], the roles focusing on evaluator relationships with stakeholders and fourth, the situational generated roles.

However the categories are varied and multiple and the social scientist adopts multiple roles in response to particular contexts, we join the critic made by Skolits et al. [20]: little has been said on the roles' specificity in regard of the evaluation contexts. Nevertheless, they state, "(...) in practice, evaluators often find that they change and enact specific roles in response to the demands of specific evaluation activities" [21]. Segerholm [22] also insists on the importance to consider the contextual elements of the evaluation activity to understand the researcher's role. Following Skolits et al.[23], we argue that instead of viewing roles from a macro orientation such as an evaluator's overall purpose, choice of methodology, or an intended relationship to stakeholders, roles are more realistically viewed from the perspective of the common activities that an evaluator engages with throughout an external evaluation process.

\section{Return on researcher's activities}

Following those statements, we have chosen an inductive and a pragmatic approach based on our empirical experience with ONDRAF/NIRAS. Three elements are taken into consideration: the evaluation activities, the evaluation demands, and the evaluator role responses [24]. Accordingly, the starting point of the analysis consists of the common evaluation activities. The purpose is to highlight beyond them, the position of the social scientist with the different actors he engages with. To do so, we mobilize Laurent and Van Oudheusden's [25] analytical frame. Originally applied in the case of nanotechnologies, this frame is embedded in a science technology and society literature (STS) and allows studying the experimental normative positions of the social scientist. According to the authors, the experimental normativity could be understood as "a pragmatic attitude towards engagement that implies systematic probing of the roles and contributions social scientists assume throughout their engagements" [26]. In this frame, three kind of normative commitments are distinguished: a process mode, a critical mode and a mode inspired by ActorNetwork Theory. Each of these modes relates to one dimension; the relation of the social scientist with the actors he studies, the political relevance of his scientist work and finally, the problems the researcher deals with. In our case study, the first dimension mainly includes the relation between the researcher, his institution and the "sponsor". Accordingly, the relation between the social scientist and the public of participatory activities is touched on. Then, the political relevance of the scientific work is understood in a broader way as: how are results being used? More specifically, how have they been used by ONDRAF/NIRAS? Those three dimensions are built in regard of two primary elements: the evaluation demand's formulation (the expected role of the research) and then, the response of the researcher.

Two objects of case study are proposed: on the one hand, the past experiences of the researcher during the various phases of the participative process during and after the elaboration of 
the Waste Plan and on the other hand, the current $\mathrm{PhD}$ research. In this phase, we talk about "reflexivity-in-action".

\section{Researcher's activities in the Nuclear Waste Management in Belgium}

In Belgium, the long-term management of radioactive waste is under the exclusive competence of the ONDRAF/NIRAS. The Federal Agency of Nuclear Control $($ AFCN $•$ FANC) completes ONDRAF/NIRAS's expertise and the Belgian Nuclear Research Centre (SCK•CEN) has been studying nuclear waste management's solutions since 1974 (they focused mainly on the geological disposal in poorly indurated clay). At the moment, no institutional policy has yet been formally approved for the long-term management of longlived and/or high level waste. Two Belgian contextual assessments could be done. Firstly, the ONDRAF/NIRAS is an "entrepreneur" of public policy. He formulates the problem in an understandable language for the political elites [27] (e.g. the Waste Plan), he maintains the problem permanently in the systematic agenda and insures the institutional agenda setting of B\&C waste. Secondly, his action (including the elaboration of Waste Plan) is embedded in a long-term process in which the scientific and technical knowledge's move forward the geological disposal. As a consequence, the debate on nuclear waste management is step by step narrowed down to a problem of social acceptance regarding the geological disposal. Barthe [28] who has already observed this phenomenon in France explains that as soon as the process of technical aspects of the problem seems to be resolved, then arise the problem of social acceptance of this proposed solution. According to Lits [29] this reformulation of the problematic implies to focus, first, on the communication and the collaboration between the different concerned social groups and, second, on the building of participatory decision tools which facilitate the communication.

Convinced that there is a lack of societal understanding about the B\&C waste management's solution, ONDRAF/NIRAS decided to organize a participative program (to 2009 until 2011) during the elaboration of the Waste Plan. It is composed of four parts: eight participatory Dialogues, the Interdisciplinary Conference, the Citizens Conference and the legal public consultation. Even if the legal public consultation is an obligation in the decision-making process, the societal consultation deliberately organized on the initiative ONDRAF/NIRAS is something totally new in B\&C waste management in Belgium.

Each of those components was composed of different publics; interested Belgian citizens, organizations from civil society, experts and a panel of 32 citizens representative of Belgium society. In addition, ONDRAF/NIRAS outsourced the organization of the Citizens Conference. Indeed, it has been managed by an independent Belgian organization: the King Baudouin Foundation. The rest has been mainly taken in charge by ONDRAF/NIRAS. But the organization requires the help of further Consulting Companies; Dialogue Center SARL (for the coordination and the facilitation of participatory Dialogues), Greenfacts asbl (to chair of Interdisciplinary Conference and the using of his address book), Ivox (for the advertising of the events, to contact participants and to select the participants of Citizens Conference). The entire process was overseen and assessed by an Audit Committee. This committee was composed of C. Zwetkoff (University of Liège), W. Weyns (SAFIR 2 Scientific Committee) and L. Goorden (University of Antwerp). Two researchers have also followed the entire participative process: C. Parotte (University of Liège) and G. Lits (University of Louvain).

After the adoption of Waste Plan by the ONDRAF/NIRAS Board of Directors on 23 September 2011, University de Liège (C. Zwetkoff, C. Fallon, C. Parotte, S. Paile) and University of Antwerp (A. Bergmans, K. VanBerendoncks) collaborated on a one-year project financed by ONDRAF/NIRAS. The purpose of this "action research" was to analyze retrospectively and prospectively the Waste Plan.

As it has been previously stated, the Waste Plan was only the first step in a long decision-making process. By consequence, while pursuing researches on societal aspects of B\&C waste, ONDRAF/NIRAS stands as a "sponsor" for whoever engages in such participatory methodologies. In this case, the PhD student (C. Parotte) needs to think out a way to construct an inter-organizational innovative communication system that would be participative, transparent and embedded in a long-term perspective.

\section{Researcher as external evaluator: an unambiguous role}

The social scientist had several roles during and after the societal consultation. Firstly, ONDRAF/NIRAS appointed him as a member of the Audit Committee. He was a process supervisor in charge of an assessment of the two parts of the societal consultation process (Participatory Dialogues and Interdisciplinary Conference). Secondly, on his own request and after authorizations from ONDRAF/NIRAS and from the King Baudouin Foundation, the social scientist followed the Citizens Conference as an external evaluator. His aim was to adopt the critical sociologist's position. During those steps, the researcher was introduced to the participants as a participatory observant. Thirdly, the researcher also acted as an external evaluator assessing the process from an external standpoint during the one-year project which came after the societal consultation. Indeed in this third role he analyzed ex post the state of relevant law, administrative documents, theoretical and empirical scientific literature, as well as media coverage related to the Waste Plan. In each of those cases, the researcher acts as an external evaluator. His role is given either by ONDRAF/NIRAS or by a result of his own request.

The difficulties that the researcher faced are numerous, although quite common. So are the researcher's responses to deal with. These difficulties concern the negotiation of the contract, valorization of produced results and the pitfalls of the methodological approach. As process supervisor, the researcher had to produce a final assessment report based on prefixed pragmatic purposes (declined in few questions) that were originally defined by ONDRAF/NIRAS. The researcher's 
challenge was to reformulate the initially prefixed questions and to explain the methodological approach used to answer it. Then, the Audit committee supplies the answers in his own frame. Even if this frame is not the same as ONDRAF/NIRAS, it is also legitimizing through the role given and attempted of external evaluator. As a participatory observant, we felt the methodological difficulty of detachment. The few number of participants during the participatory dialogues occasions a change of role implying different levels of engagement. Indeed, the social scientist became observant participant. As Soulé [30] warns us, the intense participation of the researcher may momentarily very well spoil his lucidity and his intellectual availability. The only solution for the researcher was to render explicit this bias and to assess it in his final report. As a spontaneous external evaluator, the researcher didn't meet the same difficulties than as a process evaluator (he is entirely free to define the purposes' assessment). The evaluation demand didn't come from ONDRAF/NIRAS. Indeed, the Belgian Agency who has delegated the management of the Citizens Conference, has judged useless the need of requiring once again to the Audit Committee. As consequence, the main difficulty lied in the valorization of produced results. The political relevance of the evaluation report was nearly nonexistent; ONDRAF/NIRAS and King Baudouin Foundation barely had a look at the conclusions and the report didn't appear on the Waste Plan website. For the one-year project, two difficulties are noted: the contract's negotiation and the project's valorization. The definition of the purposes was the first issue. Once again, this situation refers to the classical relationship between a sponsor and the evaluator about the content of the contract [31]. Except for one point: here again, the demand arose from the researcher. Therefore, ONDRAF/NIRAS might refuse any proposition made by the Universities. Every word, every sentence was the source of manifold interpretations: ONDRAF/NIRAS wishes straight answers whereas Universities strive for some room in the execution of the contract so as to avoid having to answer another authority's questions and concerns throughout their research, instead of their own. But at the same time when the contract is established by an agreement between both parties, the role attributed to each actor is clear. Then, the evaluators select the methodological tools that suit the best to a given situation according to the context and the given advantages [32]. The second issue concerned the valorization of the project. At the end of it, the question of the reports' advertising created new possible disagreements. ONDRAF/NIRAS wished to get a summary report. The six reports must be transformed in scientific articles but the researcher was not allowed to diffuse the reports.

First, the analysis highlights that the researcher usually offers his expertise to assess the decision-making process of the $\mathrm{B} \& \mathrm{C}$ waste. Except for the first participatory activity, the researcher is proactive and ONDRAF/NIRAS adopts a "waitand-see" attitude. Therefore, there is no gap between the role attempted and the role adopted. This statement could have consequences on the work's valorization of the research, the contract's negotiations, etc. In our study case, the main researcher's issue is to be listening. He must be able to "interest", to be "perceptive", to be a "public speaker" for the objects that he brings into the public scene [33]. His first target is ONDRAF/NIRAS as this organization may provide him with financial support. Another issue for the researcher is to be able to incorporate his own results in tools, "dispositifs" that raise their readability. Secondly, the analysis also reveals that more than the political relevance of his results, the role of the social scientist is especially perceived as politically relevant for the actors. The demand of ONDRAF/NIRAS to create an Audit Committee is a perfect illustration: the Belgian Agency requires it as a guarantor. The social scientist was called up to guarantee an informed and fair debate [34]. As Wendling stresses: the social scientist and his sociological methods are sometimes involved more to legitimize a process or a policy solution than to actually influence it [35]. Finally, this study points out that the role of the researcher is clear. His study object, the aims of the researches and the valorization of the product results are well defined.

\section{The hybrid role of the $\mathrm{PhD}$ researcher in action}

$\mathrm{A} \mathrm{PhD}$ research is now being carried out as a follow-up of the one-year research described above. This $\mathrm{PhD}$ research has been conceived for three purposes. Firstly, the research is based on the conclusions of the summary report to move forward and raise new research questions among which one is regarded as an unanimous demand from all stakeholders. This conclusion focuses on the creation of an innovative communication system that would be participative (able to integrate all the stakeholders), transparent and embedded in a long-term perspective. Secondly, this action research is also a foresight research. That means that in the Belgian case, where the law doesn't forbid anything in this field and where a consensus exists on this need, the creation's perspective of the researcher seems limitless. Thirdly, as seen in the previous cases, it is once again the social scientist that proposes the project. Contrarily to the one-year project, the interest of the research was not discussed. The proposition of the PhD Student seems to fulfill the expectations of ONDRAF/NIRAS, as it is an extension of a project already supported by the Organism.

The $\mathrm{PhD}$ researcher's difficulties derive from three uncertainties. Firstly, ONDRAF/NIRAS is still waiting for a government's decision on B\&C waste. Secondly, the foresight dimension of the project is also a challenge for the Organism. The legal decision making process (still in building) has to be think step by step. Thirdly, ONDRAF/NIRAS is not able to assess the researcher's potential influence on the process.

Those uncertainties have some consequences on the $\mathrm{PhD}$ Research. The first one is the redefinition of the object of the PhD. The Organism feels not comfortable with the idea of a $\mathrm{PhD}$ researcher seeking to closely include relevant stakeholders in a short term in the legal decision-making process. ONDRAF/NIRAS desires to be cautious: the Organism doesn't want to take the risk that the subjects' choices for interviews, the choice of a restricted area for the study or yet the sole 
presence of the researcher could be erroneously interpreted as meaning a earlier choice of siting by the local population and the stakeholders (or more broadly any person liable to be included in the legal decision-making process). In a context where ONDRAF/NIRAS decides to progress step by step, the foresight dimension of the project becomes a sensitive point of the negotiations on the research's definition. The researcher must adapt his area of study in order to focus on the communication department of the Organizations that manage $\mathrm{B} \& \mathrm{C}$ waste. The second consequence concerns the methodological constraints related to the object's redefinition. This change creates a new difficulty considering that one of the studying subjects is also the sponsor. Then, the object of the research is an issue for the researcher as well the observed actor. The social scientist must also deal with two activities in tension. On the one hand, he evaluates the practices of his sponsor and on the other side he is the co-designer of a project that targets, among others, this sponsor. Wendling describes the role of the embedded researcher in teams of natural scientists and engineers for reflexive work. She explains (citing Webster 2007) [36] that this position is "sometimes also seen as a danger by social scientists themselves, because it could compromise the critical position they try to maintain." Practically, few questions deserve to be asked: How is the ambiguous status of the $\mathrm{PhD}$ student going to be considered within the communication department of ONDRAF/NIRAS? Which new role(s) will the actors invest him with? What will be the consequences of these various roles and their combination with the research?

\section{Social scientist on board in NWM}

All steps previously analyzed highlight the embedding of the social scientist in the field of the nuclear waste management. According to Thoreau [37], five cumulative components of the enrollment diagnostic can be declined. First, it needs an elusive debate; the topic's definition is unclear, endless and in building. Even if the technical management of nuclear waste seems to have a predefined direction, it's not the case of the so-called "societal aspects" of the problem. Each actor involved in the process of discussing those aspects can find his own way to circumvent and question it. Second, the embedded social scientist feeds the scientific and political activities. He must produce a result which may be used directly for policy-making purposes, so as to strengthen a particular outcome (i.e. a decision). The researcher's interest is to meet the practical expectations of the sponsor. Third, the actions of the social scientist are legitimated by a number of actors or tools which, all together, carry about a pragmatic window of opportunity. The mission of the social scientist is thus recognized and demanded and he is invited to occupy a certain "space" expected out of him. Fourth, the social scientist is dispossessed of the capacity to raise his own frames, problems or narratives (e.g methodology used for $\mathrm{PhD}$ ), which are imposed among others by the sponsor. Finally, he becomes considered as an "expert", in the sense that he is supposed to carry out hard evidence and certainty whereas, most of the time, "societal" issues are fluctuant and uncertain. To some extent, his knowledge production may not speak to concerned groups anymore, and thus shy away from the problem at stake.

Regarding those components, we can conclude that the $\mathrm{PhD}$ student is enrolled, on board with the topic of nuclear waste management. Our results fit with the definition stressed by Thoreau to define the enrollment of the social scientist: the dynamic of mobilization is no more questioned. The social scientist has integrated the institutional frames that may neither be questioned anymore.

\section{STATUS OF THE RESEARCHER IN ACTION IN THE FUTURE: WHICH ISSUES?}

\section{The dilemmas of the researcher}

Berling and Bueger [38] distinguish three core dilemmas in the world of practice in the every day life of the critical researcher. First, "the truth dilemma"; "science speaks truth to power and delivers scientific certainty on which grounds policy can be based." Second, the researcher's autonomy that includes his ability to choose his own methods and research question. Third, the management of knowledge travels: how to limit the possible misunderstanding of any voyage knowledge? Pichault et al. [39] join the statements of Berling and Bueger: the researcher must generate valid information (stresses the contextual conditions of the study), be legitimate and follows the tool that he contributes to apply with his action.

\section{Discussion}

Assuming the status of social scientist "enrolled" on his study object, this part of the paper aims to challenge the future issues the researcher "in action" must face. Starting point of discussion, this part keeps in mind our introduction's question: how should the social scientist engage with the actors he studies?

It results from Quimper conference that the main point of the embedded researcher is to question his independency. As stress Berling and Bueger [40] the autonomy "is often seen as a prerequisite for systematically knowledge that is not "tainted" by various forms of interests (political, economic, status.)" The new challenge of the researcher is to define and to build his independency.

To do so, the first challenge of the researcher is to question regularly his role; being transparent about one's own position in social, political contexts and his study's object [41-42]. This self-reflexivity could also include the requirement of "the subjectivity audit" [43]. For the researcher, it implies to identify the own elements of subjectivity that appears during the research process (choice of the topic, the result's valorization, his entrance on the field) [44]. Recognizing it is considered as a part of scientific rigor [45].

The second challenge is to use the hybrid role (of codesigner and evaluator) as an advantage. The researcher can also oscillate between the two roles to make round trip. This round trip creates attachment and detachment at the same time. Then, first, the social scientist will be presented as participatory 
observant to the sponsor's Department communication. In this case, identified more as a critical sociologist, being co designer is a second optional role. The critics feed the design but also legitimate his independency. Here, we must be aware of what we call the "vicious circle" of critical sociologist: being independent means be actively critical.

Being a participatory observant permits to assume our participation in a complex activity, with hybrid roles on the ground. But time periods are also saved in the planning researcher to create detachment space.

Finally, another way to deal with the hybrid status is the creation of a "specific tutorship" [46]. In this study cas, the tutorship is double. On one side, there is a $\mathrm{PhD}$ committee (composed of academics) and on the other side there is an ONDRAF/NIRAS committee. This collaborative tutorship is a room to question the frame of the thesis.

\section{CONCLUSIONS}

In regard of those analyzes and as Lits [47] stresses, it can be concluded that the commitment of the researchers in social sciences comes essentially down to "interessement" work from the social sciences in the nuclear waste problematic. In other words, the challenge of these social scientists is to be able to embed the question of the societal aspects into the nuclear field and to transform their research object so that relevant actors consider them as essential interlocutors for this question. Nowadays, he's got one contextual advantage on his side: the need of social scientists is no more questioned. In this context, the $\mathrm{PhD}$ research follows the new action field advised by the Social Sciences at the moment. No more interest to the definition of acceptance risks or the uncertainty's perceptions. The researcher made the choice of reducing the social nuclear problem to a question of communication or collaboration between different social groups [48].

The ability of the researcher to orientate his study's object is challenged. Callon stresses the importance of the choices made by the researcher when he has to decide to "connect" or to "detach" from the actors under study. According to Thoreau [49], those embeddings are numerous and remain the $\mathrm{PhD}$ researcher's choice. However the status imposed by the "action research" creates new challenges [50]. Indeed, does the researcher have really the choice to "detach" from ONDRAF/NIRAS? Answer is: no. Assuming this, further questions come, such as "how to deal with our new ambiguous status" and "how to deal with the organization?" And therefore: "how to build the independency of the researcher?"

\section{REFERENCES}

[1]Parotte C., (2013). "Gestion à long terme des déchets nucléaires belges moyennement et hautement radioactifs: Construire un dispositive communicationnel et dialogique mais comment?", Actes du Colloque EREID La Recherche en sciences humaines, pour qui, pour quoi?, Quimper, $4-5^{\text {th }}$ april 2013, pp.23
[2]Parotte, C., (2013). "social scientist on board in long-term management of high level and/or long-lived radioactive waste in Belgium", Seminar BSTS, Leuven, 13 ${ }^{\text {th }}$ june 2013.

[3]Directive 2011/70/EURATOM du Conseil du 19 juillet 2011 établissant un cadre communautaire pour la gestion responsable et sûre du combustible usé et des déchets radioactifs.

[4]Lits, G., (2013 in press). " 'Il faut des sociologues!' Analyse du rôle des chercheurs en sciences sociales dans la gestion des déchets radioactifs." pp.24.

[5]Minon, J.-P., (2011). Entretien sur l'historique de la gestion des déchets nucléaires.

[6]Skolits, G. J., et al., (2009). "Reconceptualizing Evaluator Roles." Americal Journal of Evaluation, 30(3), pp.275-295.

[7]Laurent, B. and Van Oudheusden, M. (2013, in press). "Shifting and Deepening Engagements: Experimental Normativity in Public Participation in Science and Technology." Sciences as Culture, pp. 23.

[8]Lits, G., (2013 in press). "Curiosité ou engagement? Panorama historique du rôle des chercheurs en sciences sociales dans la gestion des "aspects sociaux" du nucléaire. Francq B.", Actes du Colloque "la curiosité en sociologie". Louvain-La-Neuve.

[9]Bonano, E., et al., (2011). "Can Repository Scientists and Social Scientists Work Together to Find Solutions to Nuclear Waste Management Problems? A Repository Scientist's Perspective." Risk, Hazards \& Crisis in Public Policy 2(1).

[10]Lits, G., (2013 in press). "Curiosité ou engagement? Panorama historique du rôle des chercheurs en sciences sociales dans la gestion des "aspects sociaux" du nucléaire. Francq B.", Actes du colloque "la curiosité en sociologie". Louvain-La-Neuve.

[11]Skolits, G. J., et al. (2009). "Reconceptualizing Evaluator Roles." Americal Journal of Evaluation 30(3), pp.275-295.

[12]Laurent, B. and Van Oudheusden, M., (2013, in press). op. cit.

[13]Jones, Irwin cited in Muller, P. \& Surel, Y. (1998). L'analyse des politiques publiques, Paris.

[14]Lits, G., (2013 in press). Curiosité ou engagement? Panorama historique du rôle des chercheurs en sciences sociales dans la gestion des "aspects sociaux" du nucléaire, op. cit.

[15]Lits, G., (2013 in press). "“Il faut des sociologues!' Analyse du rôle des chercheurs en sciences sociales dans la gestion des déchets radioactifs.", op. cit.

[16]Wendling, C., (2012). "What role for social scientists in risk expertise?" Journal of Risk Research 15(5), p.484

[17]Ibid.

[18]Skolits, G. J., et al. (2009). op. cit.

[19]Weiss, H. C., (1979). "The many meanings of research utilization." Public Administration Review 39((5)): 426-431.

[20]Skolits, G. J., et al. (2009). op. cit.

[21].Ibid.

[22]Segerholm, C., (2002). Evaluating as responsibility, conscience, and conviction. In: SCHWANDT, K. E. R. T. A. (ed.) Exploring evaluator role and identity. Greenwich 
[23]Skolits, G. J., et al. (2009). op. cit.

[24] Ibid.

[25]Laurent, B. and Van Oudheusden, M. (2013, in press). op. cit.

[26]Ibid. p.189

[27]Paliodeau cited in Muller, P. \& Surel, Y. (1998). L'analyse des politiques publiques, Paris.

[28]Barthe, Y. (2006). Le pouvoir d'indécision. La mise en politique des déchets nucléaires. Collection Etudes Politiques, Economica, Paris, pp.239

[29]Lits, G. (2013, in press). "Le temps long de la "mise en politique" des déchets radioactifs belges. Élargissement des acteurs et changement de problématisation." Chaplier M. et al., Terres (dés)humanisées : ressources et climat. Académia.

[30]Soulé, B. (2007). "Observation participante ou participation observante? Usages et justifications de la notion de la participation observante en sciences sociales." Recherches Qualitatives 27, pp.127-140.

[31]Tourmen, C. (2008). "Les compétences des évaluateurs de politiques publiques." Formation emploi(104): pp.53-65.

[32]Mc Guire and al. (2002). cited in Tourmen, C. (2008). op. cit. p.55

[33]Callon, M. (1999). "Ni intellectuel engagé, ni intellectuel dégagé: la double stratégie de l'attachement et du détachement." Sociologie du travail 41: 65-78.

[34]Goorden, L., Weyns, W. \& Zwetkoff, C., (2009). Rapport d'audit global des Dialogues de l'ONDRAF néerlandophones et francophones et de la Conférence Interdisciplinaire, organisés par 1'ONDRAF. Bruxelles: Université d'Anvers, Comité Scientifique SAFIR 2, Université de Liège.

[35]Wendling, C. (2012). op. cit.

[36]Webster (2007). cited in Wendling, C. (2012), op. cit., p.488

[37]Thoreau, F., (2013). Embarquement immédiat pour les nanotechnologies responsables. Comment poser et re-poser la question de la réflexivité. Thèse de doctorat en sciences politiques et sociales STS, Université de Liège, p.366-378.

[38]Berling, T. V. and C. Bueger (2013). "Practical reflexivity and political science: Strategies for relating scholarship and political practice." PS - Political Science and Politics 46(1): p.116.

[39]Pichault F., Lisein, O., Rondeaux, G., Xhauffain, V., La recherche-intervention peut-elle être socialement responsable?, Vuibert, AGRH, p.8

[40]Berling, T. V. and C. Bueger (2013). op. cit.

[41]Ibid.

[42]Pichault F., Lisein, O., Rondeaux, G., Xhauffain, V., op. cit.

[43]De Lavergne, C. (2007). "La posture du praticien-chercheur : un analyseur de l'évolution de la recherche qualitative." Recherches Qualitatives Hors Série - Actes du colloque Bilan et prospectives de la recherche qualitative (3),p.34

[44]Ibid.

[45]St-Cur Tribble and Saintoge, (1999). p. 123, cited in De Lavergne, C., (2007), op. cit., p.35

[46]Ibid. p.38
[47]Lits, G. (2013 in press). Curiosité ou engagement? Panorama historique du rôle des chercheurs en sciences sociales dans la gestion des "aspects sociaux" du nucléaire. op. cit.

[48]Ibid.

[49]Thoreau, F., (2013). op. cit.

[50]Ibid. 